\title{
Evaluation of crab apples for apple production in high-density apple orchards
}

\author{
Soon-Il Kwon · Jingi Yoo · Jinwook Lee $\cdot$ Yong-Sun Moon C Cheol Choi $\cdot$ Hee Young Jung • \\ Dong Hoon Lee $\cdot$ Chang Kil Kim • In-Kyu Kang
}

Received: 15 September 2015 / Revised: 21 September 2015 / Accepted: 21 September 2015

(c) Korean Society for Plant Biotechnology

\begin{abstract}
Crab apple cultivars, 'Maypole', 'Tuscan', and 'Manchurian', were evaluated as potential pollinizers of major apple cultivars, 'Fuji', 'Hongro', and 'Tsugaru', cultivated in high-density apple orchard systems. Numerous cultivar characteristics, including blooming time, pollen germination, fruit set, disease and pest resistance, and selfincompatibility, were examined. The blooming times of both 'Maypole' and 'Tuscan' ranged from April 19 to May 5, which was 2-4 days earlier than those of the major commercial apple cultivars. PCR analysis did not reveal the presence of any of the S-alleles (S1, S3, S7, or S9) identified in major commercial apple cultivars. In addition, the percentage of the fruit set was high after trees were artificially fertilized with crab apple pollen. Artificially cross-pollinated fruits were of similar or higher quality than
\end{abstract}

$\dagger$ These authors contributed equally to this work.

S. I. Kwon ${ }^{\dagger}$

Apple Research Institute, National Institute of Horticultural \& Herbal Science, RDA, Kunwi 39000, Republic of Korea

J. G. $\operatorname{Yoo}^{\dagger} \cdot$ C. Choi $\cdot$ C. K. Kim $\cdot$ I. K. Kang $(\bowtie)$ Department of Horticultural Science, Kyungpook National University, Daegu 41566, Republic of Korea

e-mail: kangik@knu.ac.kr

J. W. Lee

Department of Horticultural Science, Mokpo National University, Muan 58554, Republic of Korea

Y. S. Moon

Department of Horticulture and Life Science, Yeungnam University, Gyeongsan 38541, Republic of Korea

H. Y. Jung

College of Agriculture and Life Science, Kyungpook National University, Daegu 41566, Republic of Korea

D. H. Lee

Planning and Coordination Division, National Institute of Horticultural \& Herbal Science, RDA, Wanju 55365, Republic of Korea open-pollinated fruits. They also demonstrated resistance to apple blotch, sooty blotch, and fly speck. The results indicate that the two crab apples, 'Maypole' and 'Tuscan' would be potential candidates for pollinizers of major apple cultivars in Korea. Use of the pollen of these crap apples in commercial production will improve fruit quality and promote sustainable and robust fruit production.

Keywords Blooming time, Pollen germination, Selfincompatibility, Fruit set, High-density orchard system

\section{Introduction}

Apple (Malus domestica Borkh.) is known as a gametophytic self-incompatible flowering tree. Thus, sustainable performance and fruit production in apple require the maintenance of genetically different cultivars. Flowering crab apples of different $S$-genotypic cultivars are often planted in orchards specifically to act as pollinizers. When different cultivars are grown in one apple orchard, many aspects of cultivation become more challenging, including harvesting, pest and disease control, and pruning. This is mainly due to differences in cultivar characteristics.

Recently, crab apples have been increasingly planted as pollinizers in small-scale single-cultivar apple orchards, as well as in large-scale apple orchards planted with various cultivars. This increases the efficiency of fieldwork and reduces working expenses. Thus, crab apples have been planted as pollinizers in single-cultivar apple orchards worldwide since the 1960s (Church et al. 1983; Gothard 1994; Paek 1977; Way and Paek 1976; Williams 1967, 1970; Williams and Church 1983). They have been also selected (Kim et al. 1979) and bred (Ha and Shim 1995), when their blooming times are similar to those of major apple cultivars in Korea. Four flowering crab apple cultivars have been selected for pairing 
with 'Fuji' and 'Gamhong' (Kang et al. 2002), and three have been selected for 'Hongro' (Kang 2004). However, these selected crab apple cultivars grow quickly and vigorously, making their growth difficult to control. These cultivars need to be cautiously monitored when used as pollinizers, to ensure the optimization of fruit growth.

'Fuji' has long been the most popular apple cultivar in Korea, and its production is up to $63.5 \%$ of the total production of apples in the country, followed by 'Hongro' $(10.6 \%)$ and 'Tsugaru' (6.9\%). Taken together, these cultivars constitute $81 \%$ of the apple production in Korea. High-density planting is a method employed in order to enhance yield. Because apple trees are planted at a high density per unit area, the spaces between individual trees are narrow, making it necessary to carefully control tree growth. When apple trees grow quickly, their foliage inhibits light transmission. This increase in light interception may lead to poor fruit coloration, and to impede pest and disease control. Eventually, the result will be a decrease in yield.

'Maypole' and 'Tuscan' are flowering crab apple cultivars bred in East Malling, UK in 1986. The 'Maypole' has red leaves and flowers, and red pre-mature fruits, while the 'Tuscan' has white flowers and fruits that only turn red in sunlight. Both cultivars are of the columna type, with very limited side branch growth (Shogo 2008). Therefore, the cultivar characteristics of 'Maypole' and 'Tuscan' were tested in this study, and evaluated as potential pollinizers for use with high-density planting apple orchards in Korea.

\section{Materials and Methods}

\section{Plant Materials}

'Fuji', 'Hongro', and 'Tsugaru' apple cultivars were used in this study. Three blooming crab apples were selected as pollinizers for experiments: 'Maypole', 'Tuscan', and 'Manchurian'. They were grown in the experimental field of the Apple Research Institute in Kunwi, Republic of Korea from 2005-2006. Their cultivar characteristics were compared with those of the known pollinizer cultivar, 'Manchurian'. While the dominant commercial apple cultivars were grafted onto M.26 rootstocks in 1994, seedlings of 'Maypole' and 'Tuscan' were planted, and 'Manchurian' was grafted onto M.9T337 rootstocks. The trees were then each planted in $4 \mathrm{~m} \times 2 \mathrm{~m}$ plots. The flowering characteristics of 'Fuji', 'Hongro', and 'Tsugaru' were examined, including flowering times and flowering periods. Mature anthers were collected from both 'Maypole' and 'Tuscan', but 'Manchurian' anthers were harvested just prior to flowering. After growing in an incubation room at $25^{\circ} \mathrm{C}$, the pollen was isolated and stored in a $-80^{\circ} \mathrm{C}$ deep freezer. Three trees from both the 'Maypole' and 'Tuscan' cultivars were selected. A total of 60 flowers ( 20 per tree) was collected, and the number of anthers per flower examined. To determine anther germination rate, a small amount of purified pollen was inoculated on a slide glass covered with $1 \%$ agar containing $20 \%$ sucrose, and incubated at $25^{\circ} \mathrm{C}$ for $24 \mathrm{~h}$. Germinated pollen was stained with cotton blue and then observed under a compound microscope $(\times 40$ magnification). The cultivar characteristics of the flowering crab apples 'Maypole', 'Tuscan', and 'Manchurian' were evaluated. Average tree width and the length of one-year-old new branches were measured. The number of flower clusters per branch, the number of flowers per flower cluster, and the number of anthers per flower was examined every $30 \mathrm{~cm}$ along the branches.

\section{Evaluation of Cultivar Characteristics}

In all, 150 pollen grains of the 'Maypole' and 'Tuscan' cultivars were artificially transferred onto the stigmas of commercial apple flowers. Fruit set was calculated by counting the number of fruits per artificially pollinated inflorescence, and comparing the result with the fruit set of naturally pollinated flowers. Trees were randomly arranged, and three replicates of the experiment were performed on each tree. Fruit quality was evaluated via the evaluation of fruit shape, fruit weight, flesh firmness, soluble solid content, titratable acidity, and fruit color. Flesh firmness was measured using a Fruit Tester (FT011, Italy), and the value was converted into Newtons $(\mathrm{N})$. The soluble solids content was measured using a digital refractometer (DBX-55, Japan), and titratable acidity was measured via titration with $0.1 \mathrm{~N}$ $\mathrm{NaOH}$ and expressed as gram-equivalents of malic acid. Fruit color was measured colorimetrically (Color Techno. System Co., Japan). The average value of the three points around the equatorial region of each fruit was recorded as a Hunter's a value.

\section{Examination of Pest and Disease Resistance}

Pest and disease resistance of flowering crab apples was evaluated for peach fruit moth, brown leaf spot, and sooty blotch. Three trees were selected per cultivar, and eight shoots per tree (two shoots from each direction) were chosen; thus, the leaf infection rate of 24 shoots was examined. All three trees were monitored for fruit infection. 


\section{Genomic DNA Extraction and PCR}

Genomic DNA (gDNA) was extracted from young leaves for self-incompatible $S$-genotype analysis. Young leaves were ground using a Tissuelyser (Qiagen, Germany), and total gDNA was extracted using a DNeasy Plant Mini Kit (Qiagen, Germany). The concentration of the gDNA was measured via Fluometer (TD360, Turner Biosystems, USA). The modified Broothaerts' (2003) method was used to amplify DNA via PCR and electrophoresis. S-allele specific primers for self-incompatibility analysis were FTC168 and FTC169 for S1, FTC177 and FTC226 for S3, FTC143 and FTC144 for S7, and FTC154 and FTC155 for S9 (Broothaerts 2003). The $1.5 \%$ agarose gel was stained by ethidium bromide (EtBr) for detection.

Statistical analysis

All statistical analyses were conducted using SAS version 9.3 (SAS Institute, Cary, NC, USA). The fruit set rate, fruit quality attributes, and tree performance attributes of crab apple cultivars were subjected to analysis of variance (ANOVA), and the comparison of means using Duncan's multiple range test, $p \leq 0.05$.

\section{Results and Discussion}

Flowering Time for Crab Apples and Major Apple Cultivars

Figure 1 shows the flowering times of the crab apples used as pollinizers, as well as those of major apple cultivars. While 'Fuji', 'Hongro', and 'Tsugaru' started to blossom on April 22, 21, and 23, respectively, in 2006 and 2007, the central flowers had bloomed fully on April 26, 23, and 26, respectively. The length of the flowering period of both the 'Fuji' and 'Tsugaru' cultivars was 13 days, while flowering lasted 16 days for 'Hongro' trees. 'Maypole' and 'Manchurian' started to bloom on April 19 and were fully opened on April 22. 'Tuscan' bloomed on April 20, reaching full flowering on April 23. The flowering periods of the 'Maypole' and 'Tuscan' cultivars lasted 16 days, which was one day longer than that of the well-known pollinizer cultivar 'Manchurian'. Because 'Maypole' and 'Tuscan' exhibited flowering times similar to or faster than those of common apple cultivars, these two crab apple cultivars are good pollinizer candidates for 'Fuji', 'Hongro', and 'Tsugaru'.

Pollen Properties of the Flowering Crab Apples

The pollen germination rates of 'Maypole', 'Tuscan', and

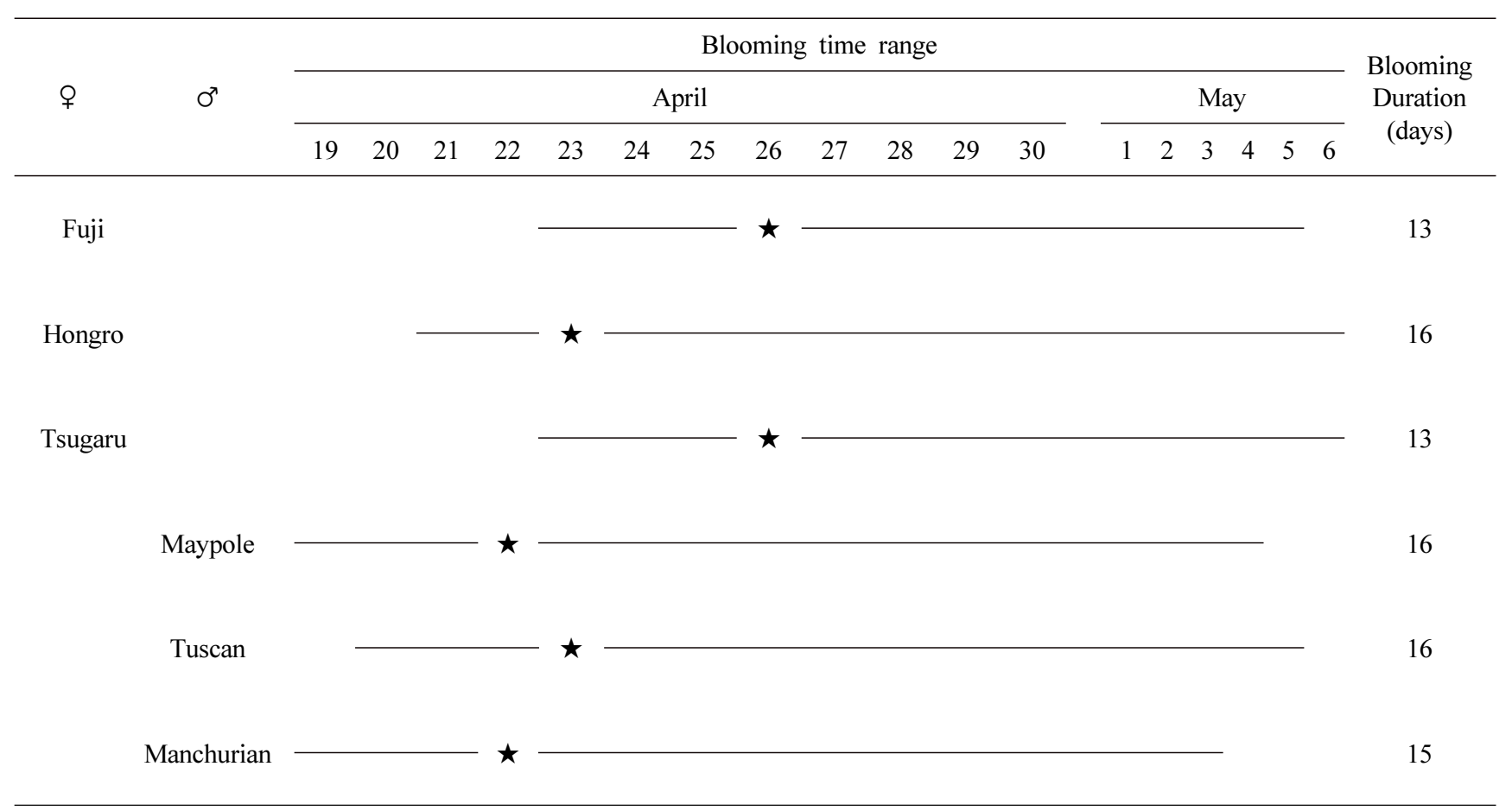

Fig. 1 Blooming time range and full blossom duration of 'Maypole', 'Tuscan', and 'Manchurian' crab apple cultivars with 'Fuji', 'Hongro', and 'Tsugaru' apple cultivars. 'Manchurian' was used as a control pollinizer. These results were obtained for consecutive two years, from 2006 to 2007 in Kunwi, Korea. A solid line (-) indicates blooming time period. Stars ( $\star$ ) indicate the date of full bloom 
Table 1 Anthers per flower and pollen germination rate of the 'Maypole', 'Tuscan', and 'Manchurian' crab apple cultivars

\begin{tabular}{ccc}
\hline $\begin{array}{c}\text { Crap apple } \\
\text { cultivar }\end{array}$ & $\begin{array}{c}\text { Anther number per } \\
\text { flower }\end{array}$ & $\begin{array}{c}\text { Pollen germination rate } \\
(\%)\end{array}$ \\
\hline Maypole & $16.0 \pm 1.2^{\mathrm{z}}$ & $52.5 \pm 3.6^{\mathrm{y}}$ \\
Tuscan & $17.8 \pm 1.4$ & $59.5 \pm 4.1$ \\
Manchurian & $18.5 \pm 1.0$ & $80.6 \pm 4.8$ \\
\hline
\end{tabular}

${ }^{\mathrm{z}}$ Data represent the mean value of 60 replications.

${ }^{\mathrm{y}}$ Data represent the mean value of 5 replications.

Table 2 Fruit set rates of major apple cultivars pollinated with 'Maypole', 'Tuscan', and 'Manchurian' crab apple cultivars

\begin{tabular}{cccc} 
& \multicolumn{3}{c}{ Fruit set rate (\%) } \\
\cline { 2 - 4 } & Fuji & Hongro & Tsugaru \\
\hline Maypole & $78.3 \mathrm{a}^{\mathrm{z}}$ & $70.3 \mathrm{a}$ & $71.6 \mathrm{a}$ \\
Tuscan & $67.2 \mathrm{a}$ & $77.8 \mathrm{a}$ & $50.4 \mathrm{~b}$ \\
Manchurian & $74.6 \mathrm{a}$ & $80.5 \mathrm{a}$ & $68.5 \mathrm{a}$ \\
\hline
\end{tabular}

${ }^{z}$ Mean separation within columns by Duncan's multiple range test at $p=0.05$.

'Manchurian' are summarized in Table 1. The average anther number per inflorescence was $16.0,17.8$, and 18.5 , respectively. The average anther number per inflorescence tended to be lower in 'Maypole' and 'Tuscan' than that of 'Manchurian'. Pollen germination rates were $52.5 \%$ and $59.5 \%$ for 'Maypole' and 'Tuscan', respectively, but $80.6 \%$ for 'Manchurian'. According to Florin's classification (30-70\% for good) (1927), 'Maypole' and 'Tuscan' are good pollinizers for major apple cultivars, as their pollen germination rates are both over $52 \%$.

Fruit Set Rate of the Flowering Crab Apples by Artificial Cross Pollination to Major Apple Cultivars

After artificial cross pollination, fruit set rate was investigated (Table 2). When 'Fuji', 'Hongro', and 'Tsugaru' were pollinated with 'Maypole' pollen, the fruit set rate was much higher than $70 \%$. When 'Tuscan' was used as a pollinizer, 'Fuji' and 'Hongro' exhibited fruit set rates of $67.2 \%$ and $77.8 \%$, respectively, while that of 'Tsugaru' was only slightly lower (50.4\%). The control 'Manchurian' exhibited a fruit set rate of over $68.5 \%$, when used with major apple cultivars. Ha and Shim (1995) reported that when pollinizers produced a fruit set rate of about $60 \%$, it can be considered high enough for agricultural purposes, as 30-40\% of fruit are pruned away after fertilization. Thus, with respect to fruit set rate, 'Maypole' and 'Tuscan' are both suitable pollinizers for the 'Fuji', 'Hongro', and 'Tsugaru' cultivars.

PCR-based S-allele Typing Analysis

PCR-based $S$-allele typing of 'Fuji', 'Hongro', 'Tsugaru', 'Manchurian', 'Maypole', and 'Tuscan' was carried out, the results of which are presented in Figure 2. The well-known self-incompatibility primers (S1, S3, S7, or S9) of apples were used for PCR (Choi et al. 2002). The results indicated that 'Fuji' has an S1S9 genotype, 'Hongro' has an S1S3 genotype, and 'Tsugaru' has an S3S7 genotype, while 'Manchurian', 'Maypole', and 'Tuscan' did not possess any $S$-allele amplified bands. These data indicate that 'Maypole' (S10S16) and 'Tuscan' (S5S10) crab apples can be used for the cross-pollination of major apple cultivars in Korea, because they possess different $S$-allele genotypes (Broothaerts et al. 2004).

Fruit Characteristics of Crab Apples and Artificially Crosspollinated Apples

Artificially cross-pollinated apples are compared with naturally pollinated fruits in Table 3. There are no statistically significant differences in fruit weight, fruit shape, soluble solids content, titratable acidity, or flesh firmness between the control (naturally pollinated with 'Manchurian' crab apple) and apples artificially pollinated with 'Maypole' or 'Tuscan' pollen. However, seed numbers were higher in artificial cross-pollination than in natural pollination with 'Manchurian'. The Hunter's a value on apple peel tissue was also higher in the 'Fuji' X 'Maypole' cross-pollination than in any other combinations. Thus, there was no variation between the results of the different pollination methods.
S1) $\begin{array}{llllll}1 & 2 & 3 & 4 & 5 & 6\end{array}$
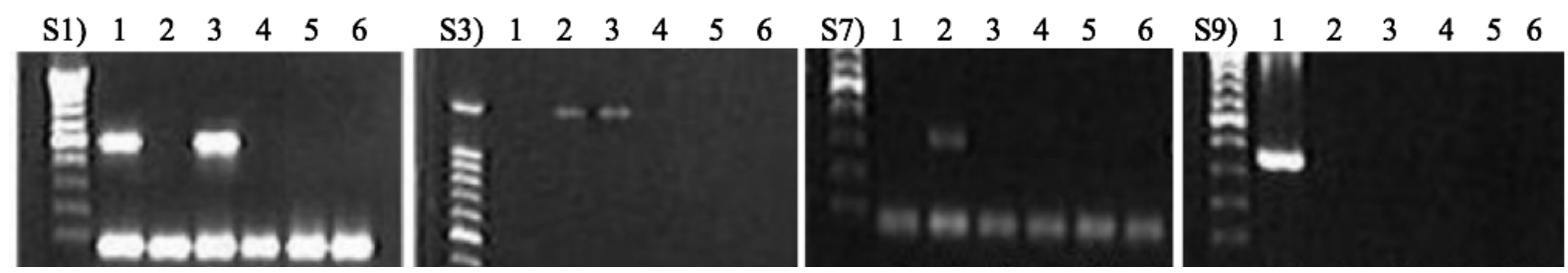

Fig. 2 PCR-based S-allele typing analysis of tested apple cultivars. S-genotype alleles used were S1, S3, S7, and S9. Lane 1: Fuji; Lane 2: Tsugaru; Lane 3: Hongro; Lane 4: Manchurian; Lane 5: Maypole; Lane 6: Tuscan 
Table 3 Fruit quality attributes of artificially pollinated apple cultivars using 'Maypole', 'Tuscan', or 'Manchurian' crab apple cultivars

\begin{tabular}{|c|c|c|c|c|c|c|c|c|}
\hline 우 & $\sigma^{x}$ & $\begin{array}{l}\text { Fruit Weight } \\
\quad\left(\mathrm{g} \text { fruit }^{-1}\right)\end{array}$ & $\begin{array}{c}\mathrm{L} / \mathrm{D} \\
\text { ratio }^{\mathrm{z}}\end{array}$ & $\begin{array}{c}\text { SSC }^{y} \\
\text { (oBrix) }\end{array}$ & $\begin{array}{l}\mathrm{TA}^{\mathrm{x}} \\
(\%)\end{array}$ & Seeds \# & $\begin{array}{l}\text { Flesh Firmness } \\
(\mathrm{N})\end{array}$ & $a^{*}$ \\
\hline \multirow{3}{*}{ Fuji } & Maypole & $334 a^{w}$ & $0.84 \mathrm{a}$ & $13.1 \mathrm{a}$ & $0.36 \mathrm{a}$ & $8.9 \mathrm{~b}$ & $27.73 \mathrm{a}$ & $20.6 \mathrm{~b}$ \\
\hline & Tuscan & $330 \mathrm{a}$ & $0.84 \mathrm{a}$ & $13.1 \mathrm{a}$ & $0.31 \mathrm{a}$ & $7.7 \mathrm{~b}$ & $26.56 \mathrm{a}$ & $19.0 \mathrm{ab}$ \\
\hline & Manchurian & 334 a & $0.86 \mathrm{a}$ & $13.4 \mathrm{a}$ & $0.33 \mathrm{a}$ & $6.7 \mathrm{a}$ & $27.93 \mathrm{a}$ & $15.6 \mathrm{a}$ \\
\hline \multirow{3}{*}{ Hongro } & Maypole & 290 a & $0.87 \mathrm{a}$ & $14.5 \mathrm{a}$ & $0.26 \mathrm{a}$ & $7.9 \mathrm{~b}$ & 29.99 a & $2.8 \mathrm{a}$ \\
\hline & Tuscan & 303 a & $0.87 \mathrm{a}$ & $13.8 \mathrm{ab}$ & $0.27 \mathrm{a}$ & $8.6 \mathrm{~b}$ & 29.99 a & $2.1 \mathrm{a}$ \\
\hline & Manchurian & $297 \mathrm{a}$ & $0.90 \mathrm{a}$ & $15.3 \mathrm{a}$ & $0.27 \mathrm{a}$ & $6.7 \mathrm{a}$ & $31.36 \mathrm{a}$ & $2.9 \mathrm{a}$ \\
\hline \multirow{3}{*}{ Tsugaru } & Maypole & $285 \mathrm{ab}$ & $0.88 \mathrm{a}$ & $12.8 \mathrm{~b}$ & $0.35 \mathrm{a}$ & $7.5 \mathrm{ab}$ & $29.99 \mathrm{a}$ & $-1.7 \mathrm{ab}$ \\
\hline & Tuscan & $278 \mathrm{a}$ & $0.85 \mathrm{a}$ & $12.4 \mathrm{ab}$ & $0.34 \mathrm{a}$ & $7.1 \mathrm{a}$ & $29.30 \mathrm{a}$ & $-2.8 a b$ \\
\hline & Manchurian & $272 \mathrm{a}$ & $0.86 \mathrm{a}$ & $11.8 \mathrm{a}$ & $0.32 \mathrm{a}$ & $6.8 \mathrm{a}$ & $29.79 \mathrm{a}$ & $1.0 \mathrm{a}$ \\
\hline
\end{tabular}

${ }^{\mathrm{z}} \mathrm{L} / \mathrm{D}$ ratio represents the ratio of fruit length to fruit diameter.

${ }^{\mathrm{y}} \mathrm{SSC}$ stands for soluble solids content.

${ }^{\mathrm{x}} \mathrm{TA}$ stands for titratable acidity.

${ }^{\mathrm{w}}$ Mean separation within columns by Duncan's multiple range test at $p=0.05$.

Pathological and Physiological Characteristics of Crab Apple Trees

It is very important that pollinizers do not introduce any diseases or pests to an agricultural environment (Crassweller et al. 1980). In this experiment, 'Maypole' and 'Tuscan' did not show any symptoms of peach fruit moth or sooty blotch infestation, but did display slight symptoms brown leaf spot, compared with those of 'Manchurian' (Table 4).

The development of crab apple trees is also critical to the

Table 4 Pathogen infection and insect infestation rates of the 'Maypole', 'Tuscan', and 'Manchurian' crab apple cultivars

\begin{tabular}{cccc}
\hline Cultivar & Peach fruit moth & Brown leaf spot & Sooty blotch \\
\hline Maypole & $\mathrm{ND}^{\mathrm{z}}$ & Very low & $\mathrm{ND}$ \\
Tuscan & $\mathrm{ND}$ & Very low & $\mathrm{ND}$ \\
Manchurian & $\mathrm{ND}$ & Very low & $\mathrm{ND}$ \\
\hline
\end{tabular}

${ }^{\mathrm{z}} \mathrm{ND}$, non-damaged; very low, $0-2$ spots per leaf.

Table 5 Tree performance attributes of the 'Maypole', 'Tuscan', and 'Manchurian' crab apple cultivars

\begin{tabular}{ccccc}
\hline Cultivar $^{\mathrm{z}}$ & $\begin{array}{c}\text { Tree } \\
\text { width } \\
(\mathrm{cm})\end{array}$ & $\begin{array}{c}\text { Shoot } \\
\text { length } \\
(\mathrm{cm})\end{array}$ & $\begin{array}{c}\text { Flower cluster \# } \\
\text { /Branch every } \\
30 \mathrm{~cm}\end{array}$ & $\begin{array}{c}\text { Flower \# } \\
\text { /Flower } \\
\text { cluster }\end{array}$ \\
\hline Maypole & $74 \mathrm{a}^{\mathrm{y}}$ & $27.8 \mathrm{a}$ & $13.9 \mathrm{a}$ & $5.2 \mathrm{a}$ \\
Tuscan & $68 \mathrm{a}$ & $21.9 \mathrm{~b}$ & $8.0 \mathrm{~b}$ & $4.0 \mathrm{~b}$ \\
Manchurian & $323 \mathrm{~b}$ & $32.7 \mathrm{a}$ & $7.5 \mathrm{~b}$ & $5.4 \mathrm{a}$ \\
\hline
\end{tabular}

'‘Maypole' and 'Tuscan' were 6 years/seedling rootstock, whereas 'Manchurian' was 10 years/M.9T337 rootstock.

${ }^{\mathrm{y}}$ Mean separation within column by Duncan's multiple range test at $\mathrm{p}=0.05$. quality and yield of commercial apples in high-density apple orchard systems, as the latters' strong growth characteristics have numerous disadvantages due to the high-density competition in such setups. The growth of 'Maypole' and 'Tuscan' is compared with that of the known crab apple cultivar 'Manchurian' in Table 5. The width of 'Maypole' and 'Tuscan' was $74 \mathrm{~cm}$ and $68 \mathrm{~cm}$, respectively. Their shoot growth was also less vigorous in 'Maypole' and 'Tuscan' than in 'Manchurian'. Overall, the growth of both 'Maypole' and 'Tuscan' trees was slower, and their shoots were smaller than those of known crab apple cultivars. 'Maypole' produced the most flower clusters (13.9) per $30 \mathrm{~cm}$ branch, and 4 flowers per flower cluster. The results indicate that 'Maypole' and 'Tuscan' could be potential pollinizer candidates for use in high-density apple orchard systems in Korea.

The use of crab apples as pollinizers has also been reported in other countries, including Japan and USA. Active research aiming to select pollinizers for commercial apple cultivars is ongoing in Japan. As 'Fuji' is a major cultivar in Korea, data from Japan could be easily applied to apple orchards in Korea, reducing the effort required to screen pollinizers for Korean apple production. Shogo et al. (2008) proposed 'Maypole' as a promising 'Fuji' pollinizer candidate, and suggested that 'Maypole' should be planted at distances of less than $10 \mathrm{~m}$, in order to increase fruit yield. This is the reason why we selected two crab apples, 'Maypole' and 'Tuscan', for possible use with Korean apple cultivars. These two crap apples could meet the pollinizer requirements suggested by Dennis (2003), including synchronized flowering time and cross-compatibility with cultivars. Thus, we suggest that 'Maypole' and 'Tuscan' be considered as potential pollinizers 
for the 'Gamhong', 'Hongro', and 'Fuji' cultivars in Korea, in order to increase fruit quality and yield in high-density apple orchards.

\section{Acknowledgments}

Financial support for this research was supported by a grant from 2014 Research Fund (PJ01048102) of Rural Development Administration, Republic of Korea.

We thank to Dr. Philip W. Becraft at Iowa State University for critical reading.

\section{References}

Broothaerts W (2003) New findings in apple S-genotype analysis resolve previous confusion and request the re-numbering of some S-allele. Theor. Appl. Genet. 106:703-714

Broothaerts W, Van Nerum I, Keulemans J (2004) Update on and review of the incompatibility $(S-)$ genotypes of apple cultivars. HortScience 39:943-947

Choi C, Tao R, Andersen RL (2002) Identification of self-incompatibility alleles and pollen incompatibility groups in sweet cherry by PCR based s-allele typing and controlled pollination. Euphytica 123:9-20

Church RM, Williams RR, Andrews L (1983) Comparison of flowering dates and pollen released characteristics of several dessert and ornamental Malus cultivars. J. Hort. Sci. 58: 349-353

Crassweller RM, Ferree DC, Nichols LP (1980) Flowering crab apples, a potential pollinizers for commercial apple cultivars. J. Amer. Soc. Hort. Sci. 105:475-477

Florin R (1927) Pollen production and incompatibility in apples and pears. Mem. Hort. N.Y. 3:87-118
Dennis Jr F (2003) Flowering, pollination and fruit set and development. In: Ferree D.C., I.J. Warrington (Ed), Apples, Botany, Production and Uses. CABI Publishing, Oxon, UK, pp. 153-166

Gothard J (1994) The use of crab apples as pollinizers in apple production. International ornamental crabapple society bulletin. Malus 8:3-8

Ha YM, Shim KK (1995) Selection of new crabapple cultivars as pollinizers for apple orchard. J. Kor. Soc. Hort. Sci. 36: 281-291

Kang IK, Lee GJ, Kim MJ, Kwon SI, Paek PY, Choi DG (2002) Selection of crab apples as pollinizers for major apple cultivars in apple orchard. Kor. J. Hort. Sci. Technol. 20:330-334

Kang IK (2004) Selection of crab apple as pollinizers for 'Hongro' apple cultivar. Kor. J. Hort. Sci. Technol. 22:212-215

Kim JH, Yiem MS, Shin YU (1979) The selection of crab apple cultivars as pollinators for single cultivar commercial apple orchards. RDA J. Agric. Sci. 21:37-44

Paek SG (1977) Evaluation of ornamental Malus species and cultivars as pollinators for single cultivar commercial apple orchards. Thesis of Cornell University. p.83

Shogo M, Takahiro E, Tsutomu M, Hiromisu K (2008) Effect of distance from early flowering pollinizers 'Maypole' and 'Dolgo' on 'Fuji' fruit set. Sci. Hort. 117:151-159

Way RD, Paek SG (1976) Pollination arrangements in new apple plantings. N.Y. State Agri. Exp. Sta. (Geneva) Special Report No. 3

Williams RR (1967) A pollinator system for the single variety Cox's Orange Pippin orchard. Long Ashton Res. Sta. Rpt. for 1966:112-114

Williams RR (1970) Factors affecting pollination in fruit trees. p.193-208. In: Luckwill. L.C. and C.V. Cutting(eds.). Physiology of tree crop. Academic Press. New York and London

Williams RR, Church RM (1983) Growth and flowering of ornamental Malus pollinators in apple orchards. J. Hort. Sci. 58:337-342 